\title{
The Representation of Poverty in the "Tanah Mama" Film by Asrida Elisabeth based on Max Weber's Perspective
}

\author{
Muhammad Hayyi' Lana Alkhan ${ }^{1}$, Atikah Marwa², Muhammad Hasyim³ \\ 1,2,3 Universitas Islam Negeri Maulana Malik Ibrahim, Jalan Gajayana No 50 Malang, \\ Indonesia \\ \{16310033@student.uin-malang.ac.id ${ }^{1}, 18720037 @$ student.uin-malang.ac.id², \\ muhammadhasyim@bsa.uin-malang.ac.id ${ }^{3}$ \}
}

\begin{abstract}
The study aims to understand the kinds of poverty, the causes of appearing poverty, and the impact of poverty towards family and society in the "Tanah Mama" film based on Max Weber's perspective. This research is a qualitative research. The data source is the "Tanah Mama" film. The techniques of data collection used are watching and noting. The techniques of data validation used are increasing persistence, triangulation, and peer discussion. The technique of data analysis used is Miles and Huberman models that consist of data reduction, data presentation, and conclusion drawing. Based on the data found and their analysis, the researchers concluded that the kinds of poverty that occurred in the "Tanah Mama" film are natural poverty and structural poverty. The causes of appearing poverty in the "Tanah Mama" film are the existence of injustice, local government policies, and low education in the village. The impacts of poverty towards family and society in the Tanah Mama film are the conflicts between families and the low prosperity of local society.
\end{abstract}

Keyword: Causes, film, impacts, kinds, poverty

\section{INTRODUCTION}

Poverty is a condition of one's inability to fulfill basic needs so that they are less able to guarantee survival. Poverty is usually described as a lack of income to meet basic necessities of life, such as food, clothing, and so on. Soelaeman stated that poverty is a lack of income to meet basic needs [1, p. 174]. Whereas Setiadi added that a group of community members is said to be under poverty if the income of this group of community members is not enough to meet the most basic needs of life such as food, clothing and shelter [2, p. 789]. The term poverty implies that poor people live in subcultures and as a result of similar experiences, where they have certain attitudes and patterns of behavior inherited from parents to their children [3, p. 19].

The factor of one's inability to fulfill their life needs can occur both from within the person and from the outside environment. Human perception of the basic needs is influenced by the level of education, customs, and the value system that is owned [1, p. 228]. Poverty is not something that manifests itself apart from other aspects but it is realized as a result of interactions between various aspects of human life. These aspects are social aspects and economic aspects [4, p. 163]. 
Humans in their efforts to meet their needs and social life will never be separated from the problem of poverty. In according with this context, Baswir and Sumodiningrat mentioned that there are three aspects that cause poverty. They are natural poverty, culinary poverty, and structural poverty [2, p. 796].

In the context of the films, poverty becomes an interesting theme. One of the film that elaborates poverty is the "Tanah Mama Film". This film was published in 2015 directed by Asrida Elisabeth. This 65-minute film tells the story of a mother named Halosina. She lives in a village in Yahukimo, Wamena. Halosina, who is often called Mama, has to struggle to support herself and her four children. When Mama's children are in hunger, Mama unwillingly steals sweet potatoes in Mama's sister-in-law's field. Even Mama apologizes, Mama is still punished. Mama must pay a fine of one pig or around 500 thousands. Not having a penny, Mama runs away from Mama's village.

According to the previous studies about poverty, the researchers find a group of studies. They are: (1) Hidayah elaborated poverty problems in Padang Bulan novel by Andrea Hirata. This study aimed to describe the constructive structure and its problem [7, p. 1]; (2) Hasbullah explained an overview of poverty in San Yan's Ma Yan Works novel by Sanie B. Kuncoro. This study aimed to describe the social context and literature as a mirror of society of the author $[8, \mathrm{p}$. viii]; (3) Nurjanna described poverty images in novel When the Lights Are Red by Hamsad Rangkuti. This study aimed to analyze the sociological aspects of literary works covering the image of poverty [9, p. v]; (4) Basid and Niswah described analyzed Hana's social act in Lovely Hana based on Max Weber perspective. This study aimed to describe and analyze Husna's social acts in the Lovely Hana's film such as causes and its effect $[19$, p. 1$]$.

In this research, the researchers aim to analyze the kinds of poverty, to understand the causes of poverty, and to know the impacts of poverty towards family and society in the "Tanah Mama" film by Asrida Elisabeth based on Max Weber's perspective. The researchers prefer to use Max Weber's perspective because the approach is more detailed in explaining the repesentation of poverty in the film. He stated that he paid more attention to ideas and effects on an economy than looking at ideas as a simple reflection of economic factors. He saw both of these as autonomous forces that can influence the world of economy [5, p. 26]. In addition, he said that what happens in the environment including poverty is a manifestation of social action. $\mathrm{He}$ is more likely to make individuals the object of study and seeks to explore an individual's actions through social action [6, p. 143].

\section{METHODOLOGY}

This research is a qualitative research This research is called qualitative research because in this study describes the representation of poverty in the "Tanah Mama" film based on Max Weber's perspective [10, p. 12]. According to Patilima, a qualitative research is an investigation process, the researchers gradually try to understand social phenomena by distinguishing, comparing, imitating, cataloging, and compiling study objects $[11, \mathrm{p} .7]$.

The main data source in this research is the "Tanah Mama" film [12, p. 141]. The techniques for data collection used are: (1) watching techniques [13, pp. 66-67]. In this step, the researchers watch the whole film to know the story and what the film talk about, watch by analyzing the kinds of poverty, their causes, and their impact towards family and society, and watch to ensure the kinds of poverty, their causes, and their impact towards family and society; (2) noting techniques [14, p. 166]. In this step, the researchers note sentences and dialogues about the kinds of poverty, their causes, and their impact towards family and society based in minute by minute. 
The data validation technique uses a three-stage creativity test. They are: (1) increasing perseverance [11, pp. 133-134]. In this step, the researchers ascertain the findings about the kinds of poverty, their causes, and their impact towards family and society is correct by reading Max Weber's perspective and watching film three times; (2) triangulation [10, p. 67]. In this step, the researchers ensure that data source used, theory used, and techniques used are correct; (3) discussions with friends and expert [10, p. 67]. In this step, the researchers discuss findings and interpretations of findings with friends and expert to make them correct, detailed, and comprehensive.

In the data analysis, the researchers distinguish the elements that make up one analysis [15, p. 171]. Technique of data analysis used in this research is the Miles and Hubermann model which consists of three steps. They are: (1) data reduction. The researchers reading, choose, and classify the findings based on the kinds of poverty, their causes, and their impact towards family and society; (2) data presentation. The researchers understand and interpret the findings based on Max Weber's perspective and categorize the sub topics that occur in the kinds of poverty, their causes, and their impact towards family and society; (3) conclusion drawing. The researchers read the all findings, their classifications, their interpretations, and their sub topics categorizations to make sure that all are correct and can be concluded [16, pp. 210-212].

\section{FINDINGS AND DISCUSSION}

\subsection{Kinds of poverty}

The poverty is hereditary and has happened before. After analyze the findings and discussion, the researchers concluded that the kinds of poverty that occur in this "Tanah Mama" film is natural poverty and structural poverty. Setiadi reveals that natural poverty is a poor condition because it was initially poor. This community group becomes poor because it does not have adequate resources both natural, human and development resources [2, p. 796]. The structural poverty is poverty caused by economic policies in the local area. This poverty comes from an unfair structure and the act of the ruling social class, which often because of the power and wealth that it possesses then exploits the poor [17, p. 178]. The detailed explanation about natural and structural poverty is shown in the table below.

Table 1. Kinds of poverty.

\begin{tabular}{ll}
\hline \multicolumn{1}{c}{ Kinds } & \multicolumn{1}{c}{ Findings } \\
\hline Natural poverty & Planting with makeshift tools, playing with \\
& traditional tools, burning wood for cooking. \\
Structural poverty & Low level of welfare, low education, minimal \\
& infrastructure, and inadequate infrastructure, \\
& family relations are less harmonious.
\end{tabular}

Based on the table above, we can see that natural poverty is planting with make shift tools. This happening can be seen when people plant crops using wood.

Mama : "Learn to dig yams from now on. So that later when you get married you

know how. After digging, close again properly (7:36).

The farmers are forced to use wood to grow their yams. Due to limited equipment, farmers in carrying out plantation activities are full of limitations. Young children are shown playing with all their limitation game tools (11:19). Villagers burn vegetables in the traditional way by stacking vegetables to sell on a pile of heated stones. (12:21). This situation shows the typology of Papuan people who still hold traditional ways. The Papuans are very dependent on surrounding natural resources. 
In education, the local government does not pay much attention. Many people who do not go to school both adults and children. So even though Papua has abundant natural resources, the people are not able to manage these resources. Then they can not complete their needs such as going to school.

Hosea: They go to school. The school in Esalim has just opened. For children from halosina, all of them don't go to school. Eli no, no Atalia, Aminus also doesn't go to school. ( 35.05)

Many of the Papuan children are not educated. This is a very unfortunate thing, because the government cannot guarante education for all people. Papuans have money that can go to school, and the others help their mothers in the garden. The unawareness government affects the low education in Papua.

And other side, the government does not pay attention to infrastructure in Papua. This is illustrated by the Papuan people who have to travel long distances, around 5 hours on foot to go to the market and to sell their produce.

Citizens : "We walk for hours until we are exhausted. at five o'clock, six o'clock. What time is it now?"

Mama : "Maybe it's eight or nine. Selling time is over. Vegetables have all withered ".( $42.40-43.07)$

\subsection{The causes of poverty}

The aspects that cause appearing poverty are the existence of injustice, low education, and local government policies. The detailed explanation about the causes of poverty is shown in the table below.

Table 2. The causes of poverty.

\begin{tabular}{cl}
\hline Causes & \multicolumn{1}{c}{ Findings } \\
\hline Existence of Injustice & $\begin{array}{l}\text { Poverty that occurs in the Papuan community is } \\
\text { caused by acts of injustice from the government } \\
\text { and from the head of the family itself. }\end{array}$ \\
$\begin{array}{c}\text { Enequal Education through Society } \\
\text { Local government } \\
\text { policies }\end{array}$ & $\begin{array}{l}\text { The government does not pay much attention to } \\
\text { the welfare of the community, especially women, } \\
\text { the lack of adequate infrastructure, the absence of } \\
\text { infrastructure development such as bridges and } \\
\text { highways. }\end{array}$ \\
\hline
\end{tabular}

Poverty is caused by acts of injustice from the government and from the head of the family itself. This is seen from the treatment of a husband to his two wives (24.04). The husband does not care about the first wife. Even though he has a lot of money, he never puts it aside (26.44). He only cares for the second wife, even though his first wife is still his legal wife and is the responsibility of the husband in fulfilling her needs.

Hosea : They go to school. The school in Esalim has just opened. For children from Halosina, all of them don't go to school. Eli no, Atalia no, Aminus also doesn't go to school. (35.05-32.38)

This shows that the children of the second wife go to school while the children of the first wife were none of them going to school. They all have equal rights in education. There is an indifference of the husband to his wife when he is punished for stealing. The husband, though guilty, still does not care about what happened to the first wife. This is considered very unfair as 
a wife and children who should get protection and a living from their husband and father. The situation shows that injustice is one of the causes of poverty in the Papuan community.

Not all children go to the school. Only for certain children who have money who can do. This illustrates the inequality of education in the area. In this context, money is the main cause of education inequality. There is no education in managing their natural wealth.

Mama : Hosea has four children and she doesn't care. How do I get money? Hosea (husband) did not make us a garden. How can I pay a fine? I can't afford to pay. Therefore I apologize (56.37).

In the other side is the absence of state legislative associations about the responsibility of a husband in children and his wife from the Papuan government. What is experienced by a wife is not only caused by an irresponsible husband, but also a lack of government attention to the welfare of women.

\subsection{The Impacts of poverty}

There are impacts of natural and structural poverty that appear in the "Tanah Mama" film. They are impact on the family is the emergence of conflict and family relations are less harmonious. The impact on society is low welfare, low education, minimal infrastructure, and inadequate infrastructure. The detailed explanation about the impact of natural and structural poverty is shown in the table below.

Table 3. The impacts of poverty

\begin{tabular}{ll}
\hline \multicolumn{1}{c}{ Impacts } & \multicolumn{1}{c}{ Findings } \\
\hline Family & Conflicts between families are caused by less \\
Society & how prosperity of local society, low education, \\
& minimal infrastructure, and inadequate \\
& infrastructures such as bridge and highways. \\
\hline
\end{tabular}

Based on the table above we can see that the impact of poverty are conflicts between families and low prosperity of local society, low education, minimal infrastructure, and inadequate infrastructure. The impact of the existence of poverty in Papua has caused conflict between families and societies. This was triggered by the poverty among them.

Mama : "We are here, men who open garden fields. It is ready for planting. Then the wife who plants as needed. Like vegetables, cabbage, union and others. But I did not have a garden and it was night. My children haven't eaten. Because of that I took yams at the sister-in-law's garden. But it turned out that I thought I was stealing. "(1.39)

The conversation describes poverty that becomes the background of thief. Family is no more important than money. The family that we know is always helping and protecting each other. In this situation is precisely the opposite. Sister-in-law who should help her sister who is in trouble instead reports her sister to the village head and demands compensation.

The effort to take the path of peace is totally ignored. Penalty is fixed. Penalty must still be paid.

Mama : We are here because the problem will be brought to the police. Hosea makes another garden to plant. Surely we can eat from there. But I don't have a garden. And children haven't eaten. Because of that I took the yams in your garden. Then it became a problem and we had to pay a fine. We don't have money to pay. That's why we came here. (52.06) 
This conversation clearly shows that the family typology in Papua is not very good. Only focus on their own lives. Mama's action was an impact because of the existence of poverty which caused a problem and conflict even with fellow families.

The poverty that hit the village was marked by low welfare in the lives of the villagers. The homes of residents are build from the surrounding natural resources and using wood and leaf midribs. Sleeping pads that are only straw (30.10). In terms of food, they also have to share.

Mama : only four potatoes? Keep two for vina. Later you will bring yams again. This is just to choke the stomach. (32.30)

The infrastructure in this village affects the welfare. In order to go to the market, the society must pass the long feet trip.

Society : we walk for hours until we are exhausted. at five o'clock, six o'clock. What time is it now?

Mama : maybe it's eight or nine. Selling time is over. Vegetables have all withered. (42.40)

This situation illustrates how low the welfare is prosperity experienced by villagers. It has an effect on social change in the village. Weber said that social change in society is closely related to the development of human rationality. The form of human rationality is in the form of tools and objectives which includes cultural aspects in the village [18, p. 47].

\section{CONCLUSIONS}

Based on the above discussion and analysis that the representation of poverty in the Tanah Mama film by Asrida Elisabeth based on Max Weber's perspective, three conclusions were obtained, namely: 1) the form of poverty that occurred in the Tanah Mama film based on Max Weber's perspective is natural poverty and structural poverty; 2) the cause of the emergence of poverty in the Tanah Mama film based on Max Weber's perspective is the existence of injustice, local government policies and low education in the village; 3 ) the impact of the existence of poverty in the Tanah Mama film based on Max Weber's perspective is the emergence of conflicts between families and low welfare experienced by local residents. Here the researcher draws the conclusion that the poverty that occurs in Papua is an act of the community itself both from the policies of the officials and from their lifestyle.

\section{References}

[1] M. Soelaeman, Basic Social Sciences: Theory \& Concept of Social Sciences, Bandung: Refika Aditama, 2008.

[2] E. M. S. d. U. Kolip, Introduction to Sociology, Jakarta: Kencana, 2011.

[3] P. B. H. d. C. L. Hunt, Sociology, Jakarta: Erlangga, 1984.

[4] I. Suhada, Basic social knowledge, Bandung: Remaja Rosdakarya, 2017.

[5] G. R. d. D. J. Goodman, Sociology Theory, Bantul: Kreasi Wacana, 2017.

[6] Y. Anwar, Sociology, Bandung: Refika Aditama, 2017.

[7] F. N. Hidayah, "Poverty Problems in Padang Bulan Novel by Andrea Hirata: Overview of Sociology of Literature and Its Implementation in Literature Learning in High School,"Indonesian Language Education Study Program, Faculty of Teacher Training 
and Education, Muhammadiyah University, Surakarta, p. 1, 2018.

[8] W. p. Hasbullah, "An Overview of Poverty in San Yan's Ma Yan Works. B. Kuncoro, Review of Sociology Sastar Ian Watt,"Indonesian Language and Literature Department, Faculty of Languages and Literature, Makassar State University, p. viii, 2018.

[9] Nurjanna, "Poverty Images in Novels When the Lights Are Red by Hamsad Rangkuti,"Indonesian Language and Literature Department, Faculty of Languages and Literature, Makassar State University, p. v, 2018.

[10] B. Rustanto, Qualitative Research on Social Work, Bandung: Remaja Rosdakarya, 2015.

[11] Raco, Qualitative Research Methods, Jakarta: Grasido, 2010.

[12] R. I. d. P. Yaniawati, Quantitative, Qualitative, and Mixed for Management, Development, and Education (Revised), Bandung: Refika Aditama, 2017.

[13] Djamal, Qualitative Research Paradigm, Yogjakarta: Mitra Pustaka, 2017.

[14] E. W. W. d. R. A. Kusumaningtyas, Theories and Practices of Quantitative, Qualitative, PTK, R \& D Research, Jakarta: Bumi Aksara, 2018.

[15] Muhammad, Language Research Methods, Yogyakarta: Ar-Ruzz Media, 2014.

[16] I. Gunawan, Qualitative Research Methods: Theory and Practice, Jakarta: Bumi Aksara, 2013.

[17] J. D. N. d. b. Suyanto, Sociology of Introduction Texts, Jakarta: Kencana, 2004.

[18] N. Martono, Sociology of Social Change, Jakarta: Rajagrafindo Persada, 2011.

[19] S. K. N. Abdul Basid, "Social Action of Husbands in Novel Indra Rahmawati Based on Max Weber Perspective," Lingua, vol. XIV, p. 1, 2018. 